NOTES

\title{
SUPPLY VERSUS DEMAND FOR EFFICIENT LEGAL RULES: EVIDENCE FROM EARLY ENGLISH “CONTRACT” LAW AND THE RISE OF ASSUMPSIT
}

Michael J. Sechler

\section{INTRODUCTION}

Judge Richard Posner contends that judge-made law converges to efficiency, and "many of the doctrines and institutions of the legal system are best understood and explained as efforts to promote the efficient allocation of resources." Though the logic of this contention has wide appeal, ${ }^{2}$ less universal is the explanation for why judge-made law becomes efficient over time. Posner suggests judges' personal or career incentives provide the impetus to maximize efficiency. ${ }^{3}$ Political objectives may also weigh heavily on judges' decisions. ${ }^{4}$

\footnotetext{
${ }^{1}$ Richard A. Posner, ECONOMic ANalysis of Law 24 (7th ed. 2007); see also Vincy Fon \& Francesco Parisi, Litigation and the Evolution of Legal Remedies: A Dynamic Model, 116 PuB. CHOICE 419, 420 (2003).

${ }^{2}$ Posner's hypothesis is not universally accepted. See Note, The Inefficient Common Law, 92 YALE L.J. $862(1983)$.

${ }^{3}$ POSNER, supra note 1 , at 556-57, 585.

${ }^{4}$ See Tracey E. George \& Lee Epstein, On the Nature of Supreme Court Decision Making, 86 Am. PoL. SCI. REV. 323 (1992); Donald R. Songer \& Stefanie A. Lindquist, Not the Whole Story: The Impact of Justices' Values on Supreme Court Decision Making, 40 AM. J. POL. SCI. 1049 (1996).
} 
The shortcomings of this judicial-motivation argument are numerous. First, "it is largely a conjecture about facts that are somewhat difficult to verify." Also, the assumption that judges have a "taste" for efficiency may be "inconsistent with the observation that many judges are at least as concerned with redistributive goals as efficiency goals." Finally, Posner's judicial-motivation argument fails to explain why the common law developed more efficiently at some points in time than others. ${ }^{7}$

A second explanation views common law development as an evolutionary process of litigation. ${ }^{8}$ This theory, first articulated by Paul Rubin ${ }^{9}$ and George Priest,${ }^{10}$ suggests that through a kind of natural selection, legal rules leading to inefficient social or economic outcomes become more likely candidates for lawsuits. The influx of such cases forces courts to grapple with inefficient legal rules and eventually supplant them with more efficient doctrines. Rubin argues that the "presumed efficiency of the common law [as] noted by Posner is due to an evolutionary mechanism whose direction proceeds from the utility maximizing decisions of disputants rather than from the wisdom of judges." 11 The focus here centers on the behavior of litigants: "[J]udges play a passive role in this view." ${ }^{.12}$ In particular, the pressure toward efficient evolution arises from the desire of parties to create precedent. Specifically, Rubin "show[s] that efficiency occurs in situations where both parties to a dispute have an ongoing interest in cases, and that

\footnotetext{
${ }^{5}$ John C. Goodman, An Economic Theory of the Evolution of Common Law, 7 J. LEGAL STUD. 393, 393 (1992).

${ }^{6}$ Todd J. Zywicki, The Rise and Fall of Efficiency in the Common Law: A Supply-Side Analysis, 97 Nw. U. L. REV. 1551, 1563 (2003) (noting further that "common experience indicates that many judges have strong tastes for distributional goals, and that they pursue these goals in their judicial role").

${ }^{7} I d$.

${ }^{8}$ See, e.g., E. Donald Elliott, The Evolutionary Tradition in Jurisprudence, 85 COLUM. L. REV. 38 (1985); Fon \& Parisi, supra note 1; Goodman, supra note 5; R. Peter Terrebonne, A Strictly Evolutionary Model of Common Law, 10 J. LEGAL STUD. 397 (1981).

9 Paul Rubin, Why is the Common Law Efficient?, 6 J. Legal Stud. 51, 51 (1977) (noting that "resorting to court settlement is more likely in cases where the legal rules relevant to the dispute are inefficient, and less likely where the rules are efficient").

${ }^{10}$ George L. Priest, The Common Law Process and the Selection of Efficient Rules, 6 J. Legal STUD. 65 (1977).

${ }^{11}$ Rubin, supra note 9, at 51.

${ }^{12}$ Keith N. Hylton, Information, Litigation, and Common Law Evolution, 8 AM. L. \& ECON. ReV. 33, 34 (2006).
} 
efficiency need not occur if one or both parties do not have such an ongoing interest." 13

Rubin's model was expanded upon by Priest, who also articulated that common-law evolution occurred along efficient lines regardless of whether it received the benefit of judicial wisdom. ${ }^{14}$ For Priest, even if judges prefer inefficient rules, legal processes would "restrain and channel judicial discretion" to create, over time, "a larger proportion of efficient rules" than inefficient rules. ${ }^{15}$ Though Priest's argument is an extension of Rubin's, the two differ on the cause of the evolution toward efficiency. More particularly, Priest rejects Rubin's contention that efficiency only occurs where parties have an interest in ongoing litigation:

[I]nefficient legal rules will impose greater costs than efficient rules on the parties subject to them. Since litigation is more likely than settlement where, ceteris paribus, the stakes of a case are greater, disputes arising under inefficient rules will be more likely to be relitigated than disputes arising under efficient rules. ${ }^{16}$

Thus, for Priest, litigation receives its impetus from the cost of the current inefficient rule rather than some desire for favorable future precedent. ${ }^{17}$ This occurs because "[i]nefficient assignments of liability by definition impose greater costs on the parties subject to them than efficient assignments." 18 Variations on and responses to Rubin and Priest's initial contributions abound. ${ }^{19}$

${ }^{13}$ Rubin, supra note 9, at 52.

${ }^{14}$ Priest, supra note 10, at 65 (noting that "efficient rules will be more likely to endure as controlling precedents regardless of the attitudes of individual judges toward efficiency").

${ }^{15} I d$. at 66 .

${ }^{16} I d$. at 65 .

${ }^{17} I d$. at 67 ("Thus the costs imposed by inefficient rules will always be higher than the costs imposed by efficient rules.").

${ }^{18} I d$. (noting further that "[e]ven where it is possible for the party legally liable to pay the other party to assume the burden of prevention, it will be necessary to invest resources to achieve this reallocation").

${ }^{19}$ See, e.g., Hylton, supra note 12; Robert Cooter, Lewis Kornhauser \& David Lane, Liability Rules, Limited Information, and the Role of Precedent, 10 BELL J. ECON. 366 (1979); William M. Landes \& Richard A. Posner, Adjudication as a Private Good, 8 J. Legal Stud. 235 (1979); Robert Cooter \& Lewis Kornhauser, Can Litigation Improve the Law Without the Help of Judges?, 9 J. LEGAL STUD. 139 (1980); George L. Priest, Selective Characteristics of Litigation, 9 J. LEGAL STUD. 399 (1980); George 
PAGE

Numerous scholars have pointed out the shortcomings of demand-side models. John Goodman ${ }^{20}$ and Todd Zywicki ${ }^{21}$ argue that the original model offered by Rubin incorrectly characterizes precedent as an absolute, rather than as a piecemeal tendency toward either buttressing or undermining an established rule. As Goodman notes, historically at common law "a binding precedent for succeeding adjudications could only arise from a series of similar decisions in separate cases."22 "For the first several centuries of the common law, therefore, single cases standing alone did not make law." 23 E. Donald Elliott criticizes Priest's reasoning, noting the "'fallacy of composition' [created] by jumping from the statement that an inefficient rule of law increases costs in individual cases to the quite different conclusion that costs are greater in the class of disputes arising under inefficient rules." 24 Elliott also notes that Priest's thesis, which relaxes and "ton[es] down Rubin's claim," "verges on the meaningless": "Literally, Priest claims only that the existing common law comes closer to economic efficiency than would some imaginary common law developed by judges with no settlement decisions by litigants." 25 Still other scholars point out that demand side models ignore supply side factors, such as $\operatorname{bias}^{26}$ and jurisdictional competition. ${ }^{27}$

L. Priest \& Benjamin Klein, The Selection of Disputes for Litigation, 13 J. Legal StUd. 1 (1984); Avery Katz, Judicial Decisionmaking and Litigation Expenditure, 8 INT'L REV. L. \& ECON. 127 (1988); Robert D. Cooter \& Daniel L. Rubinfeld, Economic Analysis of Legal Disputes and Their Resolution, 27 J. ECON. LiT. 1067 (1989); Theodore Eisenberg, Testing the Selection Effect: A New Theoretical Framework with Empirical Tests, 19 J. Legal STUD. 337 (1990); Gillian K. Hadfield, Bias in the Evolution of Legal Rules, 80 GEO. L.J. 583 (1992); Keith N. Hylton, Asymmetric Information and the Selection of Disputes for Litigation, 22 J. LEGAL STUD. 187 (1993); Paul H. Rubin \& Martin J. Bailey, The Role of Lawyers in Changing the Law, 23 J. Legal STUD. 807 (1994); Paul G. Mahoney, The Common Law and Economic Growth: Hayek Might Be Right, 30 J. LEGAL STUD. 503 (2001); Paul H. Rubin, Micro and Macro Legal Efficiency: Supply and Demand, 13 Sup. CT. ECON. Rev. 19 (2005); Jeffrey Evans Stake, Evolution of Rules in a Common Law System: Differential Litigation of the Fee Tail and Other Perpetuities, 32 Fla. St. U. L. Rev. 401 (2005); Nicola Gennaioli \& Andrei Shleifer, The Evolution of Common Law, 115 J. POL. ECON. 43 (2007).

${ }^{20}$ See Goodman, supra note 5, at 394.

${ }^{21}$ See Zywicki, supra note 6, at 1566-75.

${ }^{22}$ Goodman, supra note 5, at 394.

${ }^{23}$ Zywicki, supra note 6, at 1575.

${ }^{24}$ Elliott, supra note 8, at 68.

${ }^{25} I d$. at $68-69$.

${ }^{26}$ See Gennaoili \& Shleifer, supra note 19, and articles cited supra note 4.

${ }^{27}$ See Zywicki, supra note 6; Daniel Klerman, Jurisdictional Competition and the Evolution of the Common Law, 74 U. CHI. L. REv. 1179 (2007). 
Recent scholarship has also advanced a third explanation, namely a "supplyside" model of legal evolution. According to Zywicki, during the medieval and early modern period, intense competition existed between various courts in England "to provide the most unbiased, accurate, reasonable, and prompt resolution of disputes. ${ }^{, 28}$ Zywicki finds the impetus for this competition in two interrelated features of common law before the modern period. First, "[1]itigants could 'vote with their feet,' patronizing those courts that provided the most effective justice." 29 Second, judges' salaries were paid out of court filing fees, creating an incentive for courts to generate as much business as possible. ${ }^{30}$ Thus, Zywicki argues that jurisdictional competition provided a supply-side "push" coexistent with Rubin and Priest's demand-side "pull." ${ }^{\text {31 }}$ Daniel Klerman examined cases before and after a 1799 statute took litigant fees away from judges and arrived at "a relatively simple hypothesis: that competition among courts led to a pro-plaintiff bias in the common law." ${ }^{, 2}$ Much like Zywicki, Klerman suggests that "the institutional setting of the judiciary may have provided financial incentives which directly affected decisionmaking.",33

As with the other two explanations, a supply-side model emphasizing jurisdictional competition within a single legal system as the driving force behind efficient rulemaking stands open to several criticisms. ${ }^{34}$ In many ways, England, which for much, if not all, of the medieval period was the most highly bureaucratized and legally advanced state in Europe, ${ }^{35}$ provides an excellent test case. Although the importance of property- and contract-protecting regimes is well documented ${ }^{36}$ how such regimes form and whether or not they converge to efficiency is less well understood. Professor Miskimin finds evidence that

\footnotetext{
${ }^{28}$ Zywicki, supra note 6, at 1585; see also Bruce L. Benson, The Spontaneous Evolution of Commercial Law, 55 S. ECON. J. 644, 652 (1989) ("Several competing court systems existed in England prior to the seventeenth century.").

${ }^{29}$ Zywicki, supra note 6, at 1585.

${ }^{30}$ Id. at 1583; see also Klerman, supra note 27, at 1187-88.

${ }^{31}$ Stake, supra note 19 , at 404.

${ }^{32}$ Klerman, supra note 27, at 1220.

${ }^{33} I d$. (noting that "judicial fee income and courts with overlapping jurisdiction" created "a pro-plaintiff bias in the common law").

${ }^{34}$ See infra Part IV.

${ }^{35}$ See R.C. VAN CAENEgem, The Birth of the English Common Law 9-10 passim (2d ed. 1997).

${ }^{36}$ Daron Acemoglu \& Simon Johnson, Unbundling Institutions, 113 J. POL. ECON. 949 (2005).
} 
parliament was not the protecting institution in early modern England, noting that parliamentary acts sustained the power of inefficient urban guilds and also severely limited rural industrialization. ${ }^{37}$ As such, the task of promoting property and contract rights fell to the common law process, especially during a period of accelerated commercialization between the fourteenth and seventeenth centuries. ${ }^{38}$ Though scholarship highlights the need for efficient property and contract rules in the development of markets ${ }^{39}$ and also the common law's efforts to that end, ${ }^{40}$ a systematic examination of the development of efficient rules for this time period remains to be done. ${ }^{41}$

Using the history of "contract" this Note examines the "supply-side" model advanced by Zywicki and echoed by Klerman: that because English judges derived much of their income from the fees paid by litigants, they had a strong incentive to create more efficient rules in order to expand their jurisdiction and hear more cases. This note attempts to do several things. First, it traces the evolution of the action of assumpsit from its birth out of the writ of trespass on the case in the late fourteenth century until the early seventeenth century, by which time the writ came to fully replace older, more cumbersome and less efficient forms of action. Second, this note uses the history of assumpsit to test Zywicki's and Klerman's hypothesis.

Part II of this note outlines the common law system and the writs used to enforce contracts prior to assumpsit; Part III examines the rise of assumpsit, citing cases from common law courts c.1300-1600; and finally, Part IV evaluates the supply-side explanation for the rise of efficient rules in light of the historical evidence discussed in Parts II-III.

\footnotetext{
${ }^{37}$ HARry A. Miskimin, THE ECONOMY OF LATER RENAISSANCE Europe 1460-1600, at 92-93 (1977).

${ }^{38}$ For a different perspective, see Robert C. PAlmer, ENGLish LAW in the AgE OF THE BLACK DEATH, 1348-81 (1993).

${ }^{39}$ See John Hicks, A ThEORY of ECONOMic History 33-36 (1969).

${ }^{40}$ See Mahoney, supra note 19.

${ }^{41}$ Notable exceptions include Stake, supra note 19, and Zywicki, supra note 6, among others.

${ }^{42}$ Contract law, as we know it today, is the product of a later age. See infra Part II.
} 


\title{
II. ThE COMMON LAW AND "CONTRACT" BEFORE ASSUMPSIT
}

English common law, at least by the time of Bracton ${ }^{43}$ and perhaps even Glanvill, ${ }^{44}$ relied heavily on writs, or "forms of action." Though nineteenth-century legal reform reduced a juggernaut of arcane forms of action rooted in feudalism to a system whereby a single writ covered most actions, the original writ system left a significant impression on common law. ${ }^{45}$ In the words of F.W. Maitland: "The forms of action we have buried, but they still rule us from their graves." ${ }^{, 46}$

Historically, litigation began with a writ: a simple strip of parchment containing a letter in Latin from the king to local authorities and sealed with the royal seal. ${ }^{47}$ These writs, or forms of action, were specific and designed to deal with only a select number of narrow circumstances. No one could bring suit in the common law courts without first obtaining one of the king's writs; even then, if the particular facts of the case did not fit into a recognized form of action, the plaintiff would be without remedy. Maitland notes:

\begin{abstract}
In the reign of Henry III Bracton had said Tot erunt formulae brevium quot sunt genera actionum. There may be as many forms of action as there are causes of action. This suggests ... that in order of logic Right comes before Remedy. There ought to be a remedy for every wrong; if some new wrong be perpetrated then a new writ may be invented to meet it. ${ }^{48}$
\end{abstract}

In practice, however, the forms of action remained fixed and inflexible. The cure came in the form of legal fictions that allowed the facts of particular cases to fit into the medieval legal paradigm. In this manner, "[t]he argument from Right to Remedy is reversed and Bracton's saying is truer if we make it run Tot erunt

\footnotetext{
432 Henry Bracton, On the Laws and Customs of England (Samuel E. Thorne ed. \& trans., William S. Hein \& Co. 1997).

${ }^{44}$ Ranulf de Glanvill, The Treatise on the Laws and Customs of the Realm of England Commonly Called Glanvill (G.D.G. Hall ed. \& trans., Thomas Nelson \& Sons 1965).

${ }^{45}$ See F.W. Maitland, The Forms of Action at Common Law 1, 6-7 (A.H. Chaytor \& W.J. Whittaker eds., Cambridge UP 1997).

${ }^{46} I d$. at 1 .

${ }^{47}$ J.H. BAKER, An INTROduction to ENGLish Legal History 57 (Oxford Univ. Press 4th ed. 2007).

${ }^{48}$ MAITLAND, supra note 45, at 5 (footnote omitted).
} 
U N I V E R I T Y OF P I T T S B U R G H L A W R E V I E W

PAGE

actiones quot sunt formulae brevium - the forms of action are given, the causes of action must be deduced therefrom." by using the incredibly flexible writ of trespass, described by Maitland as "that fertile mother of actions. ${ }^{" 50}$

Trespass originated from medieval criminal law. The twelfth-century legal treatise attributed to Glanvill differentiates between civil law (i.e., personal actions and land) and criminal law (comprised of all "wrongs"). ${ }^{51}$ The Latin root of trespass - transgressio - simply means "wrong,",52 as the translation of the Lord's Prayer from the Vulgate demonstrates. ${ }^{53}$ Though this terminology may seem strange, one must bear in mind that at this time, "there is no such word as misdemeanour - crimes which do not amount to felony are trespasses. ${ }^{, 54}$ In its formative state, trespass rested on the notion of the king's peace: if a defendant breached the king's peace with force and arms (quare vi et armis), the claimant could bring a writ of trespass at common law to recover for damages. Though the necessity of vi et armis faded over the centuries, "for a while it seems essential that there should be some unlawful force, however slight, something that can by a stretch of language be called a breach of the peace., 55

Though trespass quare vi et armis came from criminal law as a single entity, by the early fifteenth century writs similar to writs of trespass - in which the plaintiff is said to bring an action upon his special case - caused the classification of two kinds of trespass: that with force and arms and that upon the special case. ${ }^{56}$ The action on the case appeared as a supplement to trespass quare vi et armis, providing a remedy for suits in which the conduct was overtly "wrong," but the resulting damage was either indirect or non quare vi et armis. Though differentiating between trespass and case at times proved problematic, the resulting damage was often an indicator. Thus, the man struck by a log thrown into a road had a remedy in trespass; the man who later stumbled over it had a remedy in

\footnotetext{
${ }^{49} I d$.

${ }^{50} I d$. at 39 .

${ }^{51}$ GLANVILL, supra note 44 , at 3.

${ }^{52}$ S.F.C. Milsom, Historical Foundations OF THE COMMON LAW 285 (2d ed. 1981).

${ }^{53}$ BAKER, supra note 47 , at 60 .

${ }^{54}$ MAITLAND, supra note 45 , at 39-40.

${ }^{55} \mathrm{Id}$. at 43 .

${ }^{56} \mathrm{Id}$. at 54 .
} 
case. ${ }^{57}$ This distinction relieved the court system from some of the absurdities pleading trespass quare vi et armis created. ${ }^{58}$

In later centuries, emerging case law created other distinctions among different kinds of actions on the case: assumpsit to cover informal contracts ${ }^{59}$ and trover to cover title to moveable goods (chattels). ${ }^{60}$ By the eighteenth century, virtually all cases brought before English common law judges sounded in trespass and case. ${ }^{61}$

But before assumpsit, medieval and early modern common law had other remedies for contract. At that time, formal contracts under seal were known as covenants and were remedied by a writ of the same name. Typically, the writ of covenant began with an order by the sheriff to the defendant to uphold the agreement (covenant) between them; refusal to do so initiated the suit in court. ${ }^{62}$ Covenant, though seemingly efficient because plaintiffs with an irrefutable case avoided costly and time-consuming court appearances, suffered from several severe drawbacks. For one, the writ required the parties to have an existing contract under seal. ${ }^{63}$ This precedent, wrote Glanvill, arose in the twelfth century because "it is not the custom of the court of the lord king to protect private agreements, nor does it

${ }^{57}$ BAKER, supra note 47 , at 64 .

${ }^{58}$ The plea rolls contain seemingly implausible cases where, for instance, blacksmiths maliciously and with force and arms broke the king's peace and slaughtered the plaintiff's horse. Lest we believe that medieval blacksmiths were inherently malicious, we must consider the likely possibility that, in shoeing the plaintiff's horse, the blacksmith negligently drove a nail into the horse's hoof such that it later died from infection. Unable or unwilling to bring suit under any other form of action, plaintiffs chose trespass. See MiLSOM, supra note 52, at 289-90.

59 Though the formal, modern law of contract did not develop until the eighteenth and nineteenth centuries, for quite some time the job of modern contract law was done de facto by trespass in assumpsit. Professor Ames is conscious of this, noting that, in discussing assumpsit, we are as much discussing the law of torts as that of contracts. This is especially true in early cases where the outcome hinges on misfeasance and, as such, takes on the distinctive appearance of a tort. J.B. Ames, The History of Assumpsit (pt. 1), 2 HARV. L. REV 1, 2-3 passim (1888).

${ }^{60}$ MaitLand, supra note 45 , at $55-58$.

${ }^{61} I d$. at 58 . There was a practical reason for the preference for trespass. Since trespass was a criminal action, guilty defendants were imprisoned and fined heavily until the damages were paid to the plaintiff; the increased loss due to fining and imprisonment provided defendants with a strong incentive to pay damages to the plaintiff in a timely manner. Additionally, a defendant who failed to show in court to answer a charge sounding in trespass could face outlawry. See id. at 40.

${ }^{62}$ PALMER, supra note 38 , at 66.

${ }^{63}$ The sealed deed requirement was known as specialty. One who produced a sealed written instrument in court was said to have proved specialty. See id. at $64-66$. 
U N I V E R I T Y OF P I T T S B U R G H L A W R E V I E W

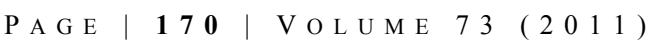

even concern itself with such contracts as can be considered to be like private agreements." ${ }^{\prime 64}$ In the words of Herle, J., "we shall not undo the law for a cartload of hay. Covenant is none other than the assent of parties that lies in specialty." 65 Thus, the writ of covenant failed to protect everyday verbal agreements between parties. $^{66}$

The writ of covenant's design as a remedy for the performance of an agreement resulted in a second problem: "[T]he court awarded damages not in place of future performance but in compensation for the period of nonperformance. ${ }^{967}$ As such, the awarded damages were almost always for the costs associated with the nonperformance of the contract, with damages originating from the transgressio being tangential. ${ }^{68}$ Consequently, covenant tended to hold for cases of nonfeasance but not misfeasance. Even if the plaintiff brought suit in covenant and proved specialty, the court could only enforce the specific performance of the contract. Thus, the carpenter covenanted to build a textile mill could be brought into court if he failed to complete the mill, but not if he built it so poorly that it collapsed. The ferryman covenanted to carry a horse across the river could have action brought against him if he failed to transport the horse, but not if he so overloaded the boat that it sank and the horse drowned. In these cases, forcing performance of the contract made little sense.

Thus, the law that could not be undone for a cartload of hay may have functioned as a disincentive for parties to engage in trade and commerce more generally. Rather than run the risk of losing money on a covenant (or sustaining damages resulting from poor performance of a covenant in excess of the contract's value), late medieval entrepreneurs may have refrained from entering into certain business agreements even during a time of increased English commercial activity. ${ }^{69}$ Consider the choices presented to a farmer: he could either sell his grain or wool locally or hire another party to transport his goods to a larger town where the demand (and price) for such goods would be higher. He would, of course, normally benefit from the agreement when the transportation costs were lower than his

\footnotetext{
${ }^{64}$ GLANVILL, supra note 44, at 132.

${ }^{65}$ YeAr Books of Edward II 1321, Vol. XXVI (pt. 2), in 86 SELdEN SOC'Y, 286 (Helen M. Cam ed. \& trans., 1969).

${ }^{66}$ PALMER, supra note 38, at 68.

${ }^{67}$ Id. at $66-67$.

${ }^{68} I d$. at 69 .

${ }^{69}$ See A.K.R. KiRAlFy, THE ACtiOn ON THE CASE 146 (1951).
} 
increased profit. However, the increased cost associated with procuring specialty and the risk that he would not be fully compensated for the carrier's negligence in the event of an accident would almost surely dissuade him from taking a risk in selling in larger markets. ${ }^{70}$

The shortcomings of covenant as an action for the efficient resolution of contract disputes are evident. And though the common law had certain remedies for the gaps left by covenant, these too presented problems for plaintiffs. Litigants used the action of debt in certain cases where covenant would not lie. ${ }^{71}$ Like covenant, debt required a contract under seal; otherwise, the case would be proved by wager of law (compurgation), in which $\mathrm{B}$ summoned a set number of compurgators (usually eleven) to testify that he owed nothing to A. ${ }^{72}$

Debt created other hindrances to those who sought the law. For one, plaintiffs could only bring the action for a fixed sum of money, the amount of which must have been agreed upon at the time of the contract itself. ${ }^{73}$ Also, litigants could not use debt in cases where the goods sold were nonexistent when the parties agreed to the sale. ${ }^{74}$ As such, a legally-protected futures market in commodities was wholly impossible at this juncture, for few entrepreneurs would be willing to make a deal for which there was no legal guarantee of performance. Similarly, debt held for cases of nonfeasance, not misfeasance. Therefore, even had a merchant successfully enforced a future sale of barley, he could not recover damages if the grain was tampered with or spoiled. Finally, recovering damages in debt presented

${ }^{70}$ Compare this hypothetical with the facts from Rogerstun $v$. Northcotes et al. (1366) in SELECT CASES of Trespass In THE King's CouRTS, 1307-1399, Vol. II, in 103 SELden SOC'Y 423-24 (Morris S. Arnold ed., 1987).

${ }^{71}$ Debt and its sister action, detinue, were very similar in form. See BAKER, supra note 47, at 321 ("The difference between detinue and debt resulted from distinguishing specific chattels, which were owned, from money or fungibles, which were owed."). Since trover and not assumpsit replaced detinue, this note does not discuss the action.

72 Though compurgation worked relatively well on the local level where a notoriously dishonest defendant would find presenting eleven men to swear under oath on his behalf difficult, at Westminster this system was impracticable and professional compurgators were hired by the defendant to testify. See $i d$. at 326 . The shortcomings of such a system are evident, especially for the plaintiff. More than any other factor, the wager of law caused debt and detinue to fall by the wayside. MAITLAND, supra note 45, at 51 surmises that debt and detinue used wager of law mainly because the writs were older than trial by jury.

${ }^{73}$ BRACTON, supra note 43 , at $181-82$.

${ }^{74} \mathrm{Id}$. 
its own set of challenges because the action relied on several ancient and inefficient mechanisms - fieri facias, levari facias and elegit - to recover damages. ${ }^{75}$

In sum, the writs of covenant and debt left the contracting parties without sufficient legal protection against problems arising from misfeasance, nonfeasance and outstanding debt in contracts. ${ }^{76}$ Professor Kiralfy suggests that a change in economic conditions during this time period brought about the pressure to make the breaches of informal contracts actionable under trespass on the case. ${ }^{77}$ Indeed, litigants during this time (or their counsel) became aware that an efficient legal rule for the enforcement of informal contracts could not come from these old writs but rather had to originate from the tort arising from the defendant's failure to successfully complete something that he took upon himself (assumpsit super se) to do.

\section{The RISE OF ASSUMPSIT}

\section{A. Misfeasance}

The problems associated with the writs of covenant and debt led litigants to try other remedies. Beginning in the reign of Edward II (1308-1327), plaintiffs occasionally brought a writ of trespass to try a case of contract. A 1313 case concerning the sale of three sacks of wool, Kemp v. Oxford, illustrates this trend. ${ }^{78}$ Oxford had placed "an immense quantity of salt in the ... wool to increase the weight" and deceive the plaintiff. ${ }^{79}$ However, the court determined

the action of the same John [Kemp], if any, is founded on the breach of a covenant made to the same John in this behalf etc. and not on any trespass or act which can redound against the king's peace. Wherefore he prays judgment etc.

\footnotetext{
${ }^{75}$ See Donald W. Sutherland, THE Assize OF Novel DisSeisin 191 (1973). In particular, fieri facias ordered the sheriff to seize and sell off the defendant's chattels to repay his debt to the plaintiff, levari facias ordered him to siphon off the defendant's revenue and elegit to seize half of his lands until the debt could be satisfied. Debt collection was further complicated by the fact that these processes could only be used in the county in which the disputed land lay.

${ }^{76}$ William S. Holdsworth, Debt, Assumpsit, and Consideration, 11 Mich. L. REV. 347, 348 (1913) (noting, for example, that with regard to debt, "[t]he limitations of its scope, and its procedural defects, made it a very unsatisfactory form of remedy for the enforcement of contractual obligations").

${ }^{77}$ See KIRALFY, supra note 69, at 146.

${ }^{78}$ Arnold, supra note 70, at 447.

${ }^{79} I d$.
} 
And John is not able to deny this. Therefore it is considered that the same John take nothing by his writ but be in mercy for his false claim. And let the aforesaid Robert go herein without day etc. ${ }^{80}$

A second, anonymous case from Michaelmas Term 1313 concerns the fraudulent sale of flax weighed down with "a great weight of hemp" but is otherwise identical. ${ }^{81}$ These cases failed because in each the court held they sounded in covenant; each plaintiff had used the wrong writ. Why did plaintiffs choose to risk losing by suing in trespass? Though we lack definitive proof, these were likely unsealed contracts. ${ }^{82}$ Left without remedy in covenant and unable to sue in debt, the plaintiffs resorted to trespass as a last, though as of yet futile, course of action.

Eventually, courts permitted trespass in contract misfeasance cases, and whether it was committed quare vi et armis became unimportant. Peculiar to these new actions was the inclusion of language claiming the "defendant 'took upon himself' (assumpsit super se) to do something, and then did it badly to the damage of the plaintiff." 83 Defendants argued the cases sounded in covenant, not in what was coming to be called assumpsit. ${ }^{84}$ The first evidence of this shift from covenant to trespass is Bukton v. Tounesende (1348), commonly called the Humber Ferry Case. ${ }^{85}$ Tounesende agreed to transport a horse owned by John de Bukton across

${ }^{80} I d$. (emphasis added).

${ }^{81}$ YEAR BOOKS OF EDWARD II 1313-14, VOL. XVI, in 39 Selden Soc'y 14 (William Craddock Bolland ed., 1922).

${ }^{82}$ See Alfred W.B. Simpson, A History of the Common Law of Contract: The Rise of the ACTION OF ASSUMPSIT 207-08 (1975). Simpson's book is unparalleled in depth of treatment but suffers from "apparently hurried preparation for the press and light proof-reading." John H. Baker, Book Review, 21 AM. J. Legal Hist. 335, 335 (1977) (reviewing Alfred W.B. Simpson, A History OF THE COMmOn LAW OF CONTRACT: THE Rise OF THE ACTION OF AsSumpsit (1975) and SAMUEL J. STOLJAR, A History OF CONTRACT AT COMMON LAW (1975)). Baker notes further, "[t]he pedantic reader will be irritated by the mutilation of judges' names ...; ; and he will also notice that about half the dates of cases are wrong by one year, presumably a result of miscalculating regnal years." Id. at 335-36.

${ }^{83}$ BAKER, supra note 47 , at 330 .

${ }^{84}$ The reader must not slip into thinking that judges from this time period were conscious of the shift away from covenant and toward trespass. They were not. Neither were these common law judges aware of the creation of case as a distinct branch of law, let alone "assumpsit." Quite to the contrary, contemporary legalists saw no radical change in contract law during the fourteenth century. Rather, these are characterizations made by more modern historians and legal academics with the benefit of hindsight. See SiMPSON, supra note 82, at 199.

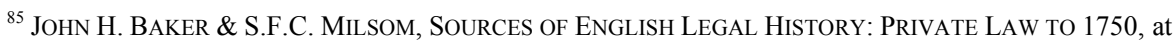
358 (1986) [hereinafter B\&M]. 
U N I V E R S I T Y O F P I T T S B U R G H L A W R E V I E W

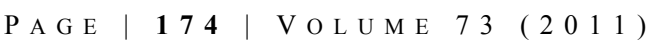

the Humber River but "so loaded the boat against John's will that he lost the aforesaid mare." 86 Tounesende argued that the case sounded of covenant, but the court replied, "[i]t seems that you did him a trespass when you overloaded his boat so that his mare perished." 87 In Stratton v. Swanlond (1374), Cavendish, J. reasoned, "a man cannot always have a clerk to make a specialty in respect of such a small matter." 88

The "trespassory" nature of the action of assumpsit appears undeniably visible in early cases. In Rogerstun v. Northcotes et al. (1366), the defendants

undertook to carry twenty quarters of wheat ... safely and securely by water, [but] ... so carelessly and negligently steered the boat in which the said wheat was put ... that for lack of control of the boat the aforesaid wheat worth twelve pounds was entirely lost. ${ }^{89}$

Similarly, in Prince v. Huish (1391), two cloth dyers

undertook at Rode well and competently to dye some cloth ... [but] so negligently and unduly dyed the aforesaid cloth there that the same William [Prince] lost a great part of the profit which he would have received from the cloth if it had been well and competently dyed, to the damage . . of ten marks. ${ }^{90}$

Other cases unfolded in a similar fashion. Suddenly, plaintiffs had viable actions against the veterinary surgeon who killed a horse while providing treatment, the carpenter who built a structure which later collapsed, and the merchant who delivered bad wine. ${ }^{91}$ The common law thus inched toward a state of economic efficiency whereby the writ of trespass encouraged contracting parties, particularly promisors, to enter into and execute contracts both in good faith and while exercising a level of precaution that minimized tortious injury to the other party.

${ }^{86} I d$. (emphasis added).

${ }^{87} I d$. at 359.

${ }^{88} I d$. at 362.

${ }^{89}$ Arnold, supra note 70, at 423-24.

${ }^{90} I d$. at $430-31$.

${ }^{91} I d$. at 424-27, 449-50. 
However, the development to this point involved tortious negligence as much as the law of contract. ${ }^{92}$

\section{B. Nonfeasance}

The legal realization that nonfeasance in contract often harmed the plaintiff and, as such, sounded in trespass, developed much slower than the same argument made with misfeasance. Even at this time, the law saw a clear distinction between not coming to the aid of a drowning man and not holding his head under the water: there was a legal duty to perform in the latter but not in the former. ${ }^{93}$ Doing something badly to the damage of another clearly sounded in trespass, but cases of nonfeasance sounded in covenant. ${ }^{94}$

What constituted a legal duty in cases of nonfeasance became the subject of great debate. An early case, Watton v. Brinth (1400), ${ }^{95}$ provides valuable insight. Laurence Watton brought "a writ [of trespass] formed on his special case" against Thomas Brinth, who had "undertaken to rebuild certain of the selfsame Laurence's houses ... within a certain time" but had not. ${ }^{96}$ Brinth's attorney argued unsurprisingly that the case sounded in covenant, and the court agreed:

BRENCHELEY. So it is. If perhaps he had counted, or if it had been mentioned in the writ, that the work had been started and then by negligence not done, it would have been otherwise ....

RIKHILL. Since you have counted on a covenant, and you have shown nothing [in proof] of it, take nothing by your writ but be in the mercy etc. ${ }^{97}$

An anonymous case from 1409 was similarly argued. ${ }^{98}$ These two cases frame the debate over assumpsit for nonfeasance until the end of the fifteenth century. Note the response given by Brencheley, J. in Watton's Case: although the court

\footnotetext{
${ }^{92}$ Ames, supra note 59, at 2-3.

${ }^{93}$ See J.B. Ames, Law and Morals, 22 HARV. L. REV. 97, 112 (1908).

${ }^{94}$ BAKER, supra note 47 , at 334 .

${ }^{95} \mathrm{~B} \& \mathrm{M}$, supra note 85 , at $378-79$.

${ }^{96} I d$. at 378.

${ }^{97}$ Id. at 378-79 (emphasis added).

${ }^{98} I d$. at $379-80$.
} 
U N I V E R S I T Y O F P I T T S B U R G H L A W R E V I E W

PAGE

recognized the truth in the defendant's charge, had the plaintiff brought the case in a slightly different manner, he may have succeeded. ${ }^{99}$ As with early misfeasance cases, litigants could not bring a nonfeasance case under covenant without specialty. Again, even had claimants proved specialty, the court would have insisted on performance and only as an afterthought awarded damages for the nonperformance, not the resulting injury.

In nonfeasance cases the protection granted to promisees appeared uncertain at best. Did the farmer who covenanted with a builder to repair a dam before the next heavy rain have an action when the builder's failure to make the repairs resulted in the flooding of the farmer's crops? Similarly, could a brewer bring assumpsit against a carrier who failed to deliver grain by a certain date such that the brewer incurred additional expenses in securing grain from a different supplier at a higher price? These examples highlight a deficiency in the law and suggest that for want of greater security when entering into agreements, litigants sought a remedy for nonfeasance under assumpsit.

The court first upheld an action of assumpsit for nonfeasance in Watkins' Case (1425), ${ }^{100}$ where Babington, C.J. argued that nonperformance of a covenant could inflict damage on a plaintiff:

Suppose someone covenants with me to roof my hall in a certain house, within a certain period, and he does not roof it on time, so that for want of roofing the timber of my house is rotted through by the rain, I say that in this case I shall have a good writ of trespass sur le matter monstré against the person who made the covenant with me: and in that case I shall recover damages because I am damaged by the nonfeasance of the [roof. Likewise here, the plaintiff is damaged by the nonfeasance of the] mill. ${ }^{101}$

Though Martin, J. bemoaned that with such reasoning "a man would have an action of trespass for every broken covenant in the world," the case succeeded. ${ }^{102}$

\footnotetext{
${ }^{99}$ KIRALFY, supra note 69, at 147 ("The judge must have meant that he would refuse to allow an action of Assumpsit based on mere failure to fulfil a promise.”).

${ }^{100} \mathrm{~B} \& \mathrm{M}$, supra note 85 , at $380-83$.

${ }^{101} I d$. at 381 (footnotes omitted).

${ }^{102} I d$. at 383 .
} 
Soon a majority of judges saw little to no difference between misfeasance and nonfeasance: under both circumstances the plaintiff suffered injury and, therefore, under both the law should provide remedy. ${ }^{103}$ Assumpsit for nonfeasance came to lie for most cases ${ }^{104}$ and was solidified in 1499 by a dictum issued in Gray's Inn by Sir John Fyneux, Chief Justice of King's Bench:

\begin{abstract}
Note, if a man makes a covenant to build me a house by a certain date, and does nothing about it, I shall have an action on my case for this nonfeasance as well as if he had built badly, because I am damaged by it. ${ }^{105}$
\end{abstract}

Thus, by the beginning of the sixteenth century, assumpsit had supplanted the writ of covenant for both cases of misfeasance, which carried with it the distinct mark of trespass, and nonfeasance, for which the transgressio was somewhat less obvious. With this development, our hypothetical farmer in Part II now had a remedy and would thus be more likely to engage in economic activities such as trade. Thus, "[t]he old law governing transactions was not changed but abandoned; and what we should call tortious remedies came to create different contractual rules." 106

\title{
C. Debt
}

Almost as soon as the Gray's Inn Dictum appeared, the question of whether assumpsit would lie for debt came before the royal courts. Although the question dominated sixteenth-century contract law, the motivation behind supplanting debt with assumpsit differed from that of replacing covenant in two very important ways. For one, cases sounding in debt, by and large, were actionable under the writ of debt. ${ }^{107}$ Second, unlike covenant, debt required no proof of specialty, provided the defendant was permitted to compurgate. ${ }^{108}$ These differences highlight why

\footnotetext{
103 The extension of assumpsit over nonfeasance cases continued to generate judicial debate until approximately 1532. See SIMPSON, supra note 82, at 269.

${ }^{104}$ See B\&M, supra note 85 , at $390-400$.

${ }^{105} I d$. at 401 .

${ }^{106}$ MiLsom, supra note 52, at 314.

${ }^{107}$ BAKER, supra note 47 , at 342 .

${ }^{108} I d$. at $342-43$.
} 
U N I V E R S I T Y O F P I T T S B U R G H L A W R E V I E W

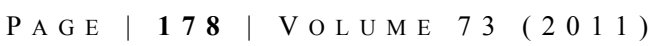

"the action of debt had lived on while covenant faded into relative unimportance.",109

However, the writ of debt had its drawbacks - compurgation, the need for a fixed sum, the mechanisms for recovering damages, and so on-and before long, litigants began bringing cases sounding in debt under assumpsit. After all, once the courts permitted assumpsit to lie in cases where the defendant failed to perform, it was not a large logical jump to argue that assumpsit would lie against the defendant who failed to pay. ${ }^{110}$ Consider an early case from 1505 :

\begin{abstract}
A man brought an action on his case, namely, that whereas he had bought from the defendant 20 quarters of malt, to be delivered to the plaintiff at a certain day, the defendant converted the said quarters to his own use...

KINGSMILL. This action does not lie, but he must have an action of debt... [to recover damages] for the wrongful withholding of the grain ....

FROWYK [C.J.] thought the contrary .... [The defendant] has done something ... . whereby I am caused loss: and so it is right that he should be punished for this wrongdoing (misdemener) by an action on the case. ${ }^{111}$
\end{abstract}

In a similar case before King's Bench, Pykeryng v. Thurgoode (1532), Spelman, J. replied to the defendant's answer of non assumpsit, "it seems that the action on the case does lie. For where a man has a wrong done to him and has sustained damage he must have an action." 112 In another case, Holygrave v. Knyghtysbrygge (1535), he elaborated:

[W] hat action should the plaintiff have? It seems to me that it is at the plaintiff's election to bring a writ of debt or this action [in

\footnotetext{
${ }^{109} I d$. at 342 .

${ }^{110} \mathrm{Id}$.

${ }^{111}$ B\&M, supra note 85 , at 408 .

112 The Reports of Sir John Spelman, Vol. I, in 93 SElden SoC’y 4 (J.H. Baker ed., 1977) [hereinafter SPELMAN I].
} 
assumpsit], or some other action; for in several cases the law gives two ways for a man to attain his remedy. ${ }^{113}$

Common Pleas did not share this view. In an anonymous case before Common Pleas in 1542, Shelley, J. stated, "[a]n action on the case does not lie in any case except where the plaintiff is without other action." 114 For the court, using assumpsit in place of debt prohibited defendants from waging their law, which was seen as the birthright of all Englishmen at common law. ${ }^{115}$ Thus, while King's Bench allowed assumpsit to supplant debt, Common Pleas consistently held that the availability of debt barred the action. ${ }^{116}$

However, An Act for Redress of erroneous Judgements in the Court commonly called the King's Bench $(1585)^{117}$ drastically changed the court system and the fate of plaintiffs bringing assumpsit. Though defendants always possessed the right to bring a writ of error before parliament, the infrequency with which the two houses met before the seventeenth century made this recourse of little good. However, under the new statute, writs of error went directly to a newly created Exchequer Chamber that contained a majority of justices from Common Pleas. ${ }^{118}$ In response to the conflict between the two courts over assumpsit, this special body of judges from the royal courts met to hear arguments in Slade v. Morley (1602). ${ }^{119}$

Slade's Case is unparalleled in importance: "Few cases have been the subject of such careful examination." ${ }^{120}$ Slade bargained and sold standing grain to Morley, who in turn agreed to pay $£ 16$ by a certain date; when the date passed with no payment, Slade brought an action of trespass on the case on an assumpsit against Morley for $£ 40 .{ }^{121}$ The jury found that the sale had occurred but that there existed

${ }^{113} \mathrm{~B} \& \mathrm{M}$, supra note 85 , at 414 .

${ }^{114} I d$. at 415 .

${ }^{115}$ THe RePORTS OF SiR JOHn SPELMAN, VOL. II, in 94 SELDEN SOC’Y 298 (J.H. Baker ed., 1978).

${ }^{116}$ Several cases underscore this split. See B\&M, supra note 85, at 417-20.

11727 Eliz. I, c. 8, in A.K.R. Kiralfy, A Source BoOK OF ENGLish LaW 66 (1957) [hereinafter SOURCE BOOK].

${ }^{118}$ SIMPSON, supra note 82, at 293.

11976 Eng. Rep. 1072.

${ }^{120}$ Kiralfy, supra note 69, at 164. See also J.H. Baker, New Light on Slade's Case (pt. 1), 29 CAMBRidge L.J. 51 (1971) [hereinafter New Light I].

${ }^{121} 76$ Eng. Rep. at 1072-73. 
U N I V E R S I T Y O F P I T T S B U R G H L A W R E V I E W

PAGE

no separate promise to pay, and referred the matter back to the court to decide if there was an action in assumpsit. After hearing arguments several times, the special court rendered judgment for Slade. Slade's Case decided unequivocally that litigants could bring an action on the case for a wholly executory contract, even where another action would lie. ${ }^{122}$ In the words of Sir Edward Coke, "every contract executory imports in itself an assumpsit."123 Slade's Case and Coke's writings on it firmly sealed the writ of debt's fate as assumpsit fully took over. ${ }^{124}$

\section{A CRitique OF The SuPPly-Side Analysis Using the HISTORY OF ASSUMPSIT}

The preceding two parts make clear that " $[\mathrm{t}]$ he development of the Action on the Case is perhaps the most important single achievement of English Common Law." ${ }^{25}$ As Professor Milsom notes, by the eighteenth century the actions of trespass and case enjoyed an almost absolute monopoly over litigation at common law. ${ }^{126}$ This holds especially true for contract law, where assumpsit not only replaced covenant and debt but also swept away a litany of old procedures that encumbered litigants and made suing successfully with either action difficult.

This shift defies easy explanation. Law and economics scholars have developed several competing theories that attempt to provide a plausible explanation. ${ }^{127}$ Zywicki and Klerman suggest a supply-side analysis. As previously mentioned, this analysis uses two features of pre-nineteenth-century common law_overlapping, concurrent court jurisdictions and judicial salaries supplemented in part by litigation fees - to describe the evolution of efficient legal rules as the product of a judicial desire for more business and, hence, more fee income.

Multiple courts with overlapping jurisdiction existed in medieval and early modern England, and this may have created the kind of "competition" between the courts Zywicki and Klerman suggest. ${ }^{128}$ And certainly judges derived a variable

\footnotetext{
${ }^{122}$ Holdsworth, supra note 76, at 351.

12376 Eng. Rep. at 1077.

${ }^{124}$ See generally KIRALFY, supra note 69; BAKER, supra note 47; SIMPSON, supra note 82.

${ }^{125}$ KIRALFY, supra note 69 , at 1.

${ }^{126}$ MiLsOM, supra note 52, at 283.

${ }^{127}$ See supra Part I.

${ }^{128}$ J.H. Baker, New Light on Slade's Case (pt. 2), 29 CAMBRIDGE L.J. 213, 217 (1971) (“To the extent that the King's Bench attitude favoured plaintiffs, the inference that its motives were partly mercenary may be justifiable.") [hereinafter New Light II].
} 
portion of their salaries from fees paid by litigants. ${ }^{129}$ Indeed, several scholars have made these assertions in the past. ${ }^{130}$ However, more current approaches to English legal history specifically and historiography more generally have hedged some of these early bets. History as a discipline is not static, and over time, prevailing attitudes toward ideas and approaches once considered "settled" change. ${ }^{131}$ For example, some earlier and well-regarded scholarship, such as Sir William Holdsworth's History of English Law, has more recently been criticized. In particular, whereas Holdsworth wrote his multivolume masterpiece using only published works, later research based on manuscripts and archival materials in the Public Records Office has refined and superseded many opinions contained in his original history. ${ }^{132}$ If handpicked quotes from Holdsworth do not pass muster for some modern scholars, this is to say nothing about a source such as Adam Smith, who wrote long before the nineteenth-century dawn of "modern" historiography ${ }^{133}$ and was not, at any rate, an English legal historian. Using such sources as the

129 See Marjorie Blatcher, The Court of King's Bench 1450-1550: A Study in Self-Help (1978).

${ }^{130}$ See, e.g., 2 AdAm Smith, AN InQuiry INTO THE NATURE AND CAUSES OF THE WEAlth OF NATions 720 (R.H. Campbell \& A.S. Skinner eds., Liberty Classics Indianapolis 1981) (1776) ("The fees of the court seem originally to have been the principal support of the different courts of justice in England. Each court endeavoured to draw to itself as much business as it could, and was, upon that account, willing to take cognizance of many suits which were not originally intended to fall under its jurisdiction.”); ADAM SMITH, LECTURES ON JURISPRUDENCE 281-82, 423-25 passim (R.L. Meek et al. eds., 1982); 5 William S. HOLDSWORTH, A HiSTORY OF ENGLISH LAW 117 (1924) (noting the rivalry between common law and other courts); BRYCE D. LYON, A CONSTITUTIONAL AND LEGAL HISTORY OF Medieval EnGLAND 443 (2d ed. 1980) (noting that "through fictitious legal means the king's bench stole much legal business from the court of common pleas" to gain more "fees, from which the justices derived much of their living"). Zywicki and Klerman rely on some of these authors in presenting their theories. See Zywicki, supra note 6, at 1584, 1588, 1595-98 passim; Klerman, supra note 27, at 1180, 1182.

131 J.H. BAKer, AN Introduction to English Legal History Preface (Butterworths $2 d$ ed., 1979) ("[A]ll history, meaning history as we see it rather than the bare facts of the past, is subject to change; and ... original research has revealed so many new facts that our interpretations of English legal history are having to change as fast as the modern law does.").

${ }^{132}$ KIRALFY, supra note 69, at 1; Richard A. Cosgrove, The Culture of Academic Legal History: Lawyers' History and Historians' Law 1870-1930, 33 CAMBRIAN L. REV. 23, 29-30 (2002) (noting that Holdsworth's History of English Law is now recognized as not having been written to modern scholarly standards; consequently, some historians treat citing it as significant authority with caution).

${ }^{133}$ Peter R.H. SleE, Learning AND A Liberal Education: The Study of Modern History in the UNIVERSITIES OF OXFORD, CAMBRIDGE AND MANCHESTER, 1800-1914, at 130 (1986) (“As a rule, no longer were historians to be concerned primarily with entertaining the reading public, with predicting the future course of politics, or with vindicating party prejudice. Their task was to increase man's knowledge of the past."). 
U N I V E R I T Y O F P I T T S B U R G H L A W R E V I E W

PAGE

bedrock of any theory without more commits the error Milsom warned historians of thirty years ago when discussing the "competition" between the courts of Kings Bench and Common Pleas: "If we see that as an event like the murder in a detective story, we shall cleverly discern a motive for it and write our own variety of legal fiction." 134

When examined in context, evidence from the development of assumpsit suggests judicial financial self-interest was not the primary —or even a relevantmotivating factor. Such a supply-side explanation seems unlikely, however, for a number of reasons. First, and most telling, is the relative slowness and uneven, unplanned pace with which the common law rules surrounding contract moved toward efficiency during this time. The development of assumpsit, for example, is generally thought to have begun in the early fourteenth century and did not conclude until the seventeenth century. ${ }^{135}$ If judges at this time were primarily concerned with increasing revenue through the generation of efficient rules, it seems counterintuitive that such changes met resistance and took several centuries to effectuate. Even with the early cases of misfeasance, which were much easier to justify than the shift from debt to assumpsit, the king's courts showed a marked hesitation to permit trespass to do the work of covenant. ${ }^{136}$ Kiralfy, for one, notes that even though "[p]ressure was constantly exerted in the fourteenth century and throughout the fifteenth century to make such informal promises enforceable," an examination of the royal court rolls from this period yields successful cases "side by side with ... a clear succession of judicial decisions, reported in the Year Books, to the effect that such actions were not tenable." ${ }^{137}$ In other words, plaintiffs bringing their cases in trespass instead of covenant succeeded-but only sometimes. Evidence from later centuries bears out this conclusion. ${ }^{138}$

Second, even in the sixteenth century, where some scholars suggest judges were anything but disinterested in their own financial gain, ${ }^{139}$ there is little evidence indicating "King's Bench began to compete for cases involving oral

\footnotetext{
${ }^{134}$ MiLSOM, supra note 52, at 61.

${ }^{135}$ See supra Part III.

${ }^{136}$ See supra Part III.A.

${ }^{137}$ KIRALFY, supra note 69, at 146.

${ }^{138}$ See supra Part III.B.; B\&M, supra note 85 , at 378-405.

${ }^{139}$ See BLATCHER, supra note 129, at 165-66; LYON, supra note 130, at 443.
} 
promises by allowing ... indebitatus assumpsit writs." ${ }^{\text {140 }}$ Much is made, for instance, out of one generalized passage written by Baker: ${ }^{141}$

It can hardly be coincidence that so much of the reform was initiated under Sir John Fyneux, who presided over the court from 1495 to 1525 when its fortunes were at their lowest ebb. He appointed his son in law John Rooper as chief clerk in 1498, and the Rooper family made its fortune from the office between then and its retirement in 1616. Cynics might criticise the judges and clerks for making the court a family business; they undoubtedly had more than a professional interest in the success of the procedures under their control. But they had no monopoly, and they thrived only by satisfying litigants and the profession at large. ${ }^{142}$

Several problems arise in using this quote as "proof" or even just evidence that common law judges such as Fyneux created more satisfactory rules in order to make money. It is even unclear exactly what Baker means in this last sentence. The sentence could mean that Fyneux and the Roopers satisfied litigants in order to thrive; it could also mean, of course, that the court satisfied litigants and it was only because of this they thrived. The difference in meaning between the two formulations is great: one suggests the court schemed to generate personal wealth and the other does not. In the context of the shift to assumpsit in the sixteenth century, the second formulation - that the court satisfied litigants and it was only because of this they thrived - seems much more plausible, and accords more fully with other statements by Baker. ${ }^{143}$ As A.W.B Simpson notes, a narrow focus on such statements overlooks the fact that many, if not most, common law judges throughout history "have conceived their primary function to be that of deciding

\footnotetext{
${ }^{140}$ Klerman, supra note 27, at 1191.

${ }^{141}$ See id. at 1184.

${ }^{142}$ BAKER, supra note 47 , at 44.

${ }^{143}$ Baker notes that though "the internecine conflicts between the courts over actions on the case ... can be associated with identifiable groups of judges ..., no one has yet dared to attribute the transformation of the common law to the vision (or avarice) of a few individual lawyers." J.H. Baker, English Law and the Renaissance, 44 CAMBRIDGE L.J. 46, 49-50 [hereinafter Law \& Renaissance] (noting further that "[t]he officials who benefited from changes in the legal system are seen rather as having reacted productively to forces outside their control"); see also New Light II, supra note 128, at 215 ("It is unlikely that the debate [over assumpsit in the sixteenth century] was principally motivated by the jealous preservation of jurisdictional boundaries for the sake of revenue from fees.").
} 
U N I V E R S I T Y O F P I T T S B U R G H L A W R E V I E W

PAGE

cases in conformity with existing law, whether they approved of the existing law or not." 144

Moreover, some of the cases in which Fyneux took part undermine the contention that he specifically - and King's Bench more generally-created rules for economic gain. We know, for example, that Fyneux supported the use of assumpsit for pure nonfeasance. ${ }^{145}$ However, it is also evident that he opposed permitting the same writ to do the work of debt. In Orwell v. Mortoft (1505), ${ }^{146}$ the parties had agreed to the sale of sixty quarters of barley, but Mortoft failed to deliver the grain. Instead of bringing suit in debt, the plaintiff "alleged that the price had been paid, that the barley had been left with the seller to be safely guarded to the plaintiff's use, and delivered on a certain day, and that the seller had undertaken (super se assumpsit) and promised to do all this." ${ }^{147}$ The court held that the action did not lie; the plaintiff needed to have brought an action in debt. ${ }^{148}$ Importantly, the reporter notes Fyneux shared this view. ${ }^{149}$ Only Frowicke C.J. ${ }^{150}$ thought assumpsit would lie, based on the fact that the money was prepaid. ${ }^{151}$ As Baker concludes, "the remark shows that the common law did not fully accept that failing to perform a promise was by itself actionable in trespass on the case." $" 152$ If we accept both the conjecture that "King's Bench began to compete for cases involving oral promises by allowing ... indebitatus assumpsit writs" $" 153$ and the suggestion that judges such as Fyneux satisfied litigants in order to thrive, we must find it odd indeed that King's Bench declined to allow pleading in assumpsit in

\footnotetext{
${ }^{144}$ SIMPSON, supra note 82, at 294.

${ }^{145} I d$. at 275 .

${ }^{146}$ B\&M, supra note 85 , at $406-11$.

${ }^{147}$ SIMPSON, supra note 82, at 288 (footnote omitted).

${ }^{148}$ B\&M, supra note 85 , at 408 .

${ }^{149} \mathrm{Id}$. at 411 ("Coming from Westminster, I heard my lord Fyneux say that in his view an action of debt would lie, in which he would recover damages for all this wrongdoing; but not this action.").

${ }^{150}$ In some places the name is Frowicke and in others Frowyk. Compare id. at 406-10, with SOURCE BooK, supra note 117 , at $150-52$.

${ }^{151}$ B\&M, supra note 85 , at 410 n.12 ("If I covenant with a carpenter to make me a house, and pay him $£ 20$ to make the house by a certain day, and he does not make the house by the day, I shall have an action on my case because of the payment of my money.").

${ }^{152}$ BAKER, supra note 47 , at 338 .

${ }^{153}$ Klerman, supra note 27, at 1191.
} 
numerous cases. ${ }^{154}$ As Jeffery Stake notes in the context of land law, "[ $[$ ] $]$ he fact that courts did not always hold for [the more efficient rule] ... indicates that the drift toward efficiency is not readily attributable to such an inclination in the judges themselves." 155

Third, any contention that King's Bench expanded its jurisdiction in the sixteenth century to siphon off business from Common Pleas using assumpsit and that Common Pleas reacted the way it did to preserve revenue ignores several important facts. The reaction of Common Pleas - banning the use of assumpsit and reversing King's Bench cases decided in assumpsit after 1585-can only be explained in terms of economic gain "[i]f it had been the case that the Common Pleas in practice enjoyed a monopoly over the action of debt." ${ }^{156}$ They did not. Thanks to prior developments in the common law, the motivation for litigants to bring cases to the King's Bench already existed. ${ }^{157}$ Thus, litigants' attraction to King's Bench over Common Pleas existed even in the absence of judges supposedly creating revenue-maximizing rules.

Finally, the type of cases litigated using assumpsit deserves attention. By and large, litigants brought small, informal contracts before the royal courts: the sale of grain, sacks of wool, and barrels of wine; the shodding or transport of a horse; the roofing of a house; and so on. ${ }^{158}$ Two reasons explain this trend. First, litigants could not practically secure a deed for such "petty" cases. ${ }^{159}$ Second, the larger contracts - those involving land, for example - always had a deed and were brought, by necessity, under the older forms of action. ${ }^{160}$ Given this, "[i]t is hard to believe that men like Frowicke C.J. or Fineux C.J., who favoured the extension of

\footnotetext{
${ }^{154}$ SIMPSON, supra note 82, at 268-69 ("The majority view in Orwell v. Mortoft (1505) frowned upon the general use of the action on the case as an alternative to debt, and ... [t] the earliest example of a court allowing assumpsit is ... a decision of the King's Bench in 1533.").

${ }^{155}$ Stake, supra note 19, at 419 (arguing further that "[i]t appears more likely that the pressures of suboptimal land use brought the resulting inefficient arrangements back to the courts for judicial invalidation").

${ }^{156}$ SIMPSON, supra note 82, at 293.

${ }^{157}$ See id. at 293-94 (noting that litigants often preferred to bring cases before King's Bench instead of Common Pleas even without the creation of assumpsit because of long-standing procedural advantages and lower litigation costs).

${ }^{158}$ See supra Part III; B\&M, supra note 85 , at $358-405$.

${ }^{159}$ SimPSON, supra note 82 , at 208.

${ }^{160}$ MiLSOM, supra note 52, at 356 ("Assumpsit was never available when the plaintiff had a document under seal. He still had to bring covenant or debt as appropriate.”).
} 
assumpsit, were likely to gain significantly by acquiring jurisdiction over a handful of trivial actions for breach of promise." ${ }^{, 161}$ Indeed, more modern research indicates that the "[w]illingness to consider new remedies can have brought Fineux [and the rest of King's Bench] no great material return either." ${ }^{" 162}$ The only way judges could have profited substantially from the extension of assumpsit would have been if the common law abandoned the requirement of sealed documents to be brought under covenant or debt, something we have already seen the royal courts were unwilling to do. ${ }^{163}$ This raises an interesting question: if King's Bench judges were competing with other courts for revenue by creating new rules, why then would they exclude the most valuable cases, which were clearly those under seal? The answer must be that they were not competing for revenue in the way Klerman and Zywicki suggest. Thus, though it may be "unfashionable," we must "look for some explanation other than mere economic self-interest."

The primary motivation behind the shift to assumpsit much more likely lies with litigants' desire for "better justice." Well before the fifteenth and sixteenth centuries, litigants had for the most part abandoned the older, local courts in favor of the king's courts because they "must have felt that "wherever the king was, there was the law." "165 There was no "deliberate and frontal attack by the kings on the local courts," but rather "the alternative offered by the royal justices was so much better." 166 Litigants desired to make assumpsit work for wrongs supposedly covered by other, older actions because they favored the king's remedy. Turning again to the Humber Ferry Case (1348), ${ }^{167}$ even if we lack hard evidence, it is apparent why the plaintiff wanted to sue in trespass: he likely lacked a written instrument, and the defendant's argument that the case sounded in covenant meant

\footnotetext{
${ }^{161}$ SIMPSON, supra note 82, at 280.

${ }^{162}$ Eric W. Ives, The Common Lawyers of Pre-Reformation England: Thomas Kebell, A CaSe STUDY 211 (1983). For a discussion of judicial revenue during this time, see $i d$. at 209-16. See also BAKER, supra note 47, at 44 ("Moreover, neither the substantive nor the procedural reforms [of the sixteenth century] had immediately visible consequences. It was nearly a hundred years after its invention before the fictitious bill of Middlesex helped reverse the decline of business, a reversal which neither Fortescue CJ nor Fyneux CJ lived to see.”).

${ }^{163}$ MiLsom, supra note 52, at 356.

${ }^{164}$ SIMPSON, supra note 82, at 294.

${ }^{165}$ VAN CAENEGEM, supra note 35, at 34 (citation omitted).

${ }^{166} I d$. at 33 .

${ }^{167}$ KIRALFY, supra note 69, at 37-39; supra Part III.A.
} 
the plaintiff should go without remedy. ${ }^{168}$ Additionally, remedy in covenant, even had the plaintiff proven specialty, made no sense. True, the defendant failed to transport the mare across the river, "[b]ut he was sued, not because it was left behind, but because it was dead." 169 To the judge, the defendant had committed a trespass in overloading the boat so that the mare drowned. Why was this so? Surely the judge was not swayed by the thought that permitting the plaintiff to succeed would bring in some additional trivial amount of revenue. The much more plausible reason is that "[i]f the facts were as stated by the plaintiff, he was entitled to a remedy; and it would be as unimportant as it is today whether the remedy was regarded as sounding in tort or contract ...." ${ }^{\prime 170}$ The requirement of specialty in covenant forced the plaintiff's attorney to come up with a novel solution; ${ }^{171}$ the court simply chose to recognize it. ${ }^{172}$

It is tempting to read into the development of assumpsit for misfeasance and later for nonfeasance a judicial motivation for expanding jurisdiction and reaping economic benefits. But if we do, we not only ignore much historical fact but also commit "the historian's deadly sin of contempt for those about whom he is writing." $" 173$ Indeed, not until the mid-sixteenth century does assumpsit gain any kind of popularity. Compared to covenant, which continued to be used to try the vast number of contract cases from the thirteenth through sixteenth centuries, assumpsit appears almost as an anomaly. ${ }^{174}$ Two examples demonstrate this point. Milsom notes,

In one term of 1564 a common pleas roll of nearly a thousand membranes has nearly a thousand actions of debt of which the entries are not merely formal, and the total of nonfeasance entries,

\footnotetext{
${ }^{168}$ BAKER, supra note 47 , at 330 .

${ }^{169}$ MiLsom, supra note 52, at 317.

${ }^{170} I d$. at 316 .

${ }^{171}$ See SIMPSON, supra note 82, at 208-09 (noting that "there seems to have been continuous pressure from litigants (or their counsel) in the fourteenth century to persuade the common law courts to accept jurisdiction over these petty cases").

${ }^{172}$ Id. at 284 (hypothesizing that courts were correcting an unfairness in the common law, namely that "some litigants [had] to use archaic and unsatisfactory forms of action simply because their particular species of complaint had been provided with a remedy early in the history of the law").

${ }^{173}$ MiLSOM, supra note 52, at 60.

${ }^{174} I d$. at 333 (noting that "[t]here is no threat to the traditional ways of making agreements enforceable; and assumpsit is still a back-door remedy for plaintiffs who would otherwise suffer hardship").
} 


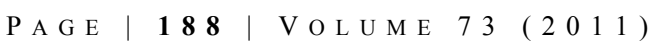

formal and other, is a little over twenty. A king's bench roll of 1557 , with just over two hundred membranes has forty-five nonfeasance entries. $^{175}$

Milsom's point is that cases of assumpsit for nonfeasance became more numerous in the King's Bench first; however, if we consider the broader implications of the relative number of different kinds of writs, it is apparent that assumpsit was indeed an anomaly. ${ }^{176}$ The surge in cases brought under actions on the case beginning in the sixteenth century is not, furthermore, the result of any kind of judicial feehunting. Rather, the falling value of money caused a flood of cases to come under royal jurisdiction; as this occurred, the anomalies became much more apparent, more numerous, and harder to ignore. ${ }^{177}$

The shift to assumpsit, if intentional, cannot be explained by reference to judicial economic self-interest. Milsom is right: if we act as detectives in a murder mystery, eventually someone will get accused. ${ }^{178}$ Instead, the motivation on the part of judges to make assumpsit work seems to be intellectual. ${ }^{179}$ Even in the sixteenth century, when the appearance of impropriety was arguably the greatest, the difference between the approaches of King's Bench and Common Pleas that eventually led to Slade's Case, for instance, can be thought of as mainly intellectual, not one motivated by financial gain. ${ }^{180}$ The Common Pleas believed assumpsit would not lie in place of debt for several reasons. For one, both

${ }^{175} I d$.

${ }^{176}$ See also KIRALFY, supra note 69, at 187-97 (detailing the instances of both older forms of action and various actions on the case between 1512 and 1586). For instance, even in 1586, the King's Bench (called Queen's Bench during this time) heard 284 debt actions during Easter Term, compared with only 42 actions in assumpsit. Id. at 196.

${ }^{177}$ MiLsom, supra note 52, at 333, 342-43.

${ }^{178} I d$. at 61 .

${ }^{179}$ New Light II, supra note 128, at 215 ("It is unlikely that the debate was principally motivated by the jealous preservation of jurisdictional boundaries for the sake of revenue from fees."); Law \& Renaissance, supra note 143, at 50 ("In so far as the changes were merely jurisdictional or procedural illusions - changes of form rather than substance - the main cause was probably not social, economic or political, but intellectual.”).

${ }^{180}$ MiLSOM, supra note 52, at 343 (noting a "difference in approach between the king's two principal courts"); New Light II, supra note 128, at 216 ("The debate [over using assumpsit in lieu of debt] seems rather to have been symptomatic of a more intellectual conflict, a final confrontation between the old learning and the new."). 
longstanding tradition and chapter 24 of the Statute of Westminster II (1285) ${ }^{181}$ held that "special writs [were permitted] only where there was no existing writ to meet the case." 182 Also the court did not believe that "a contract and a contemporaneous promise to perform it could give rise simultaneously to two distinct forms of action." 183 Finally, Common Pleas opposed assumpsit's subversion of Englishman's birthright to wage their law. ${ }^{184}$ On the other hand, because of its decisions in earlier cases, King's Bench "was forced into the position of having either to deny the principle which forbade overlapping remedies, or to argue that the principle was not infringed by its decision." 185 In Pickering $v$. Thoroughgood (1532), ${ }^{186}$ the court chose the latter:

And although Pykeryng could have an action of debt, that is immaterial; for the action of debt is founded on the debet et detinet, whereas this action is founded on another wrong, namely, the breach of the promise. ${ }^{187}$

Put differently, King's Bench saw no breach of the principle forbidding overlapping remedies, for the plaintiff had brought an action for the breach of promise, not for the underlying debt. Thus, the rationalization of the two courts, and not some myopic focus on generating revenue, set into motion several decades of conflicting court views that led both to the 1585 statute and to Slade's Case. ${ }^{188}$

\section{Conclusion}

Congruent with the idea that the adequate legal protection of property ${ }^{189}$ and contract rights encourages economic growth, ${ }^{190}$ this note has sketched out the ways

\footnotetext{
${ }^{181} 13$ Edw. I, Stat. 1, c. 24, in SOURCE BoOK, supra note 117, at 138-39.

${ }^{182}$ New Light II, supra note 128, at 217.

${ }^{183} \mathrm{Id}$. at 218.

${ }^{184} I d$. at 219 .

${ }^{185}$ SIMPSON, supra note 82, at 290.

${ }^{186}$ B\&M, supra note 85 , at $411-13$.

${ }^{187}$ Id. at $411-12$.

${ }^{188}$ BAKER, supra note 47 , at $341-45$.

${ }^{189}$ As mentioned in supra Part II, trespass in ejectment and trespass on the case in trover covered title to land and moveable goods, respectively.
} 
in which the English "contract" law developed into a more efficient legal rule during a time of accelerated commercialization and international trade. By the time the Exchequer Chamber handed down its judgment in Slade's Case, the common law had witnessed the wholesale takeover of the action of assumpsit in all areas of contract and quasi-contract law. In so doing, assumpsit provided a more efficient remedy for wronged parties than the older writs — covenant and debt — ever could.

The story to this point, of course, is largely one of historical fact; there is nothing new in suggesting that the switch to assumpsit changed the face of English contract law. The more interesting question is how the change occurred. Even with a complete record of cases, we cannot know with any degree of certainty the motivations behind judicial decision-making in any age. The records left us from medieval and early modern English law courts are incomplete and likely wholly inadequate to form any definitive statement about judicial motivation.

This Note has attempted to shed some light using the history of the action of assumpsit on the reasons for the common law's shift toward efficiency over time. By replacing older forms of action with assumpsit, common law judges may very well have been exercising their "taste" for efficiency, as Judge Posner's hypothesis suggests. ${ }^{191}$ On the other hand, judges may have just been responding to the needs of litigants who were forced to plead in assumpsit because of critical deficiencies in the older forms of action, as demand-side models suggest. ${ }^{192}$ However, there appears to be enough evidence to suggest that the shift toward efficient legal rules is not the product of naked judicial self-interest. ${ }^{193}$

However, supply-side models may well have utility. No doubt many of the common law's peculiarities are the product of a rich and complex history of which concurrent, overlapping courts of law are a necessary and important component. ${ }^{194}$

\footnotetext{
${ }^{190}$ See HiCKS, supra note 39, at 33-36; Daniel M. Klerman \& Paul G. Mahoney, The Value of Judicial Independence: Evidence from Eighteenth Century England, 7 AM. L. \& ECON. REV. 1 (2005).

${ }^{191}$ Zywicki, supra note 6, at 1563.

${ }^{192}$ See generally Rubin, supra note 9; Priest, supra note 10.

${ }^{193}$ But see Zywicki, supra note 6, at 1583 ("During the crucial centuries of the evolution of English law, judicial salaries in all courts were paid in large part from the fees paid by litigants, which provided judges with incentives to maximize the number of cases heard and to expand the jurisdictional reach of their court."); Klerman, supra note 27, at 1182 ("English judges derived much of their income from fees paid by litigants. The more litigants patronizing a particular court, the richer its judges.").

${ }^{194}$ As Maitland notes, it was difficult for contemporaries to see the forms of action as the product of both different ages and multiple courts. See MaITland, supra note 45, at 9 (The forms of action "had their origin and their explanation in a time when the king's court was but one among many courts.").
} 
And judges' self-interest surely influenced some decisions. This is only human nature. But, as this note's discussion of the development of the action of assumpsit has sought to show, judicial incomes could not have provided a primary motive for the evolution of common law doctrine. ${ }^{195}$

In sum, historical evidence suggests the hazards of asserting that medieval and early modern judges warped common law doctrines to line their pockets. ${ }^{196}$ Most significantly, that the great shift to assumpsit took close to three centuries and was resisted by the judges themselves at every stage undercuts the argument that judges were primarily acting out of self-interest. This area, of course, needs further research. A formal model that seeks to describe either the changeover to assumpsit specifically or the replacement of the old personal actions by trespass and case more generally would be particularly useful. Such a model must examine both the demand and supply sides; any theory that fails to address both in a coherent manner will lack substantial explanatory power, especially when used to analyze actual historical developments. ${ }^{197}$

${ }^{195}$ Contra Klerman, supra note 27, at 1192.

${ }^{196}$ See supra Part IV and the citations therein.

${ }^{197}$ Zywicki, supra note 6, at 1633 ("Understanding the efficiency and inefficiency of the common law, therefore, requires an understanding of the supply side of common law rule-making."). 